\title{
The competencies in English
}

\author{
Nanik Shobikah \\ English Departmeny, IAIN Pontianak, Indonesia \\ nanikshobikah@iainptk.ac.id \\ *) correspondence: nanikshobikah@iainptk.ac.id
}

\begin{abstract}
This article discusses kinds of English competences. In this article also discusses about the English language skills and components of English language use as the indicator of the student's competence. The competences of language learning are in the means of communicative competence. To reach those competences, the students must be taught and trained English language in written and oral language skill. Acquiring English as international language is the main indicator of English learning success for students. This article uses qualitative research with a literature study. The data sources are taken from textbooks, journals, articles, research finding, internet articles, newspapers, magazines, etc. The objective of this studies that the result can develop the learner's understanding about the competences in English language as the basic for the learner in learning and studying English language as the second or the foreign language in Indonesia. The finding shows that the communicative competence (communicative competences relates to the learner's ability in using language established by language knowledge, skills, and attitude including grammatical, sociolinguistic, discourse, and strategic competence) and the components of English competences (listening, speaking, reading, writing, grammar, vocabulary, and pronunciation) are must be learnt and studied by the students integrative.
\end{abstract}

Keywords: Competence; communicative competence; English competences

\section{INTRODUCTION}

Acquiring English as international language is the main indicator of English learning success for students. Generally, the competences in English learning are cognitive, psycho-motorist, and affective competences acquired by them students related to the competences in learning English. Specifically, the competence in the mean of language learning is communicative competence between students and teachers in the form of interaction inside and outside the classroom as the realization of language use for communication.

Based on some experts, communicative competence is the competence in using language correctly based on the rules of language use in society. The use of language contextually based on the mean of language use in the society and theoretically based on the rules of language pattern, so that the students must acquire the use of language contextually and theoretically. To reach those competences, the students must be taught and trained English language in written and oral language skill. Oral language skill is the skill in using the English language as the verbal or direct communication tool. This oral language skill is developed through listening and speaking skills. In this skill, the students are involved in the direct communication in the use of language as lingua franca so that there is an interaction between the teacher and the students. Meanwhile, the written language skill is touse English as a non verbal or written communication tool. The written communication is built from reading and writing skills such as reading and writing a sentence, paragraph, and text to deliver a message from the sentence, paragraph, and text.

Based on that background, the people get the communicative competence if they acquire the four language skills and components. The four language skills are listening, writing, reading, and 
speaking skills. Those four language skills can be classified into two main language skills. They are receptive and productive skills. The receptive skills are listening and reading skills and the productive skills are writing and speaking skills. Basically, those four skills cannot be acquired well if the students do not acquire English components. The students must acquire the English components as the supporting language skills such as grammar, vocabulary, and pronunciation.

This article discusses kinds of English competences divided into two main competences. They are organizational and pragmatically competences. The component of organizational competences is grammatical and textual competences, while the component of pragmatically competences is illocutionary and sociolinguistic competences. In this article also discusses about the English language skills and components of English language use as the indicator of the student's competence.

\section{METHODS}

This article uses qualitative research with a literature study. M. Nazir (2003), a literature study is a data collection technique by reviewing textbooks, literatures, notes, and reports related to the topic that must be solved. Sarwono (2006), a literature study is a research method used by collecting information from books, magazines, newspaper, and other sources to build a basic theory. The literature study has two important steps. The first step is to decide the topics. After the researcher stated the topic, the next step is doing research related the topic. In doing research, the researcher collects the data. In collecting the data, researcher collects much information from related literatures. The data sources are taken from textbooks, journals, articles, research finding, internet articles, newspapers, magazines, etc. Those data are used by the researcher to compose the research systematically.

In this article, the topic is about the competence in English language. So, the data sources are related to this topic. The data were taken from textbooks, journals, articles, research finding, and internet articles. After the researcher collected the data, the researcher composed the research systematically. The objective of this study is that the result can develop the learner's understanding about the competences in English language as the basic for the learner in learning and studying English language as the second or the foreign language in Indonesia.

This material and method as much as possible to give an idea to the reader through the methods used (Sa'aati, 2003) (references on this template is just an example). Sub-subhead on this method comprise at least on type of research; location research; materials law source; data collection technique; and data analysis (Coulson, 1968) (Brenner, 1990).

\section{RESULTS AND DISCUSSION \\ Definition of Competence}

Competence is simply defined as the one's ability established by knowledge and experiences to reach their purpose. In the psychology dictionary, Colman (2009) defined the competence as the capacity, skills, or the ability in doing something correctly and effectively. In line with Colman, Beams (2008) defined the competences as the quality of ability caused by the qualification and the ability in doing a task. Richards \& Rodgers (2003) defined the competences as the description of essential skills, knowledge, attitudes, and behaviors required for effective performance of a real-world task or activity. So, the competence is the useful ability includes skills, knowledge, attitudes, and behaviors acquired by the students in doing the real-world task or activity in the real life in form of social networking.

Permendiknas No 23/2006 explained that a competence is knowledge, behavior, and a skill needed by the students after the students experienced a learning process. Permendikbud No 54/2013 firmly explained that a competence is one's ability to behave, use a knowledge and skill to do many tasks given by the school and society. From those Permendiknas and Permendikbud legalized by the government, generally competence is including the three main components, they are knowledge, skill, and behavior. The basic differences between those regulations are in Permendiknas 
No 23/2006 determines knowledge aspect as the priority but in Permendikbud No 54/2013 determines behavior aspect as the priority. So, in Permendiknas No 23/2006, the knowledge is the central aspect followed by skill and behavior and in Permendikbud No 54/2013, the behavior is the central aspect followed by knowledge and skill. The proper of knowledge directs the one to be behaved and skilled based the one's knowledge. But, in Permendikbud No 54/2013, the learning process is more priority in building a good behavior built by the knowledge and followed by the skill. So, the students are expected having a good behavior based on their knowledge and realized by their skill.

\section{Communicative Competence}

Chomsky is the first expert showed the term of communicative competence in 1960 in his famous theory about transformational-generative grammar. Chomsky differentiated between competence and performance. Competence is defined as implicitly and explicitly knowledge towards language system of native speaker, while performance is defined as native speaker ability in producing language in the use of language. Hymens (1972) developed Chomsky's theory about competence and performance with his famous concept of communicative competence. Hymes noted that language competence is not only focus on native speaker's implicit knowledge toward language system from a certain language but it is more focus on the sociolinguistic context and aspect of language. Appropriateness in language is very important aspect because Hymes (1972)firmly stated that there are rules of use without which the rules of grammar would be useless. It means that there are many rules in language use and without the rules, the grammatical rules will be useless. It can be concluded that the grammatical rules required by native speaker of English will useless if the speaker ignores the grammatical rules in using the language.

Larsen-Freeman (2010) firmly stated that communicative competence is learner's competence using language appropriately in the certain social context. Achieving this aim, language learner must have integrative knowledge in three components such as linguistic form, meanings, and forms. Hyme's communicative competence are elaborated by Canale \& Swain (1980) Canale \& Swain proposed four competences as the basic communicative competence; they are grammatical, sociolinguistic, discourse, and strategic competences. First, the grammatical competences refers to acquire the system of language use including vocabularies, pronunciation, spelling, word formation and structure. In other words, the grammatical competences are including phonology, morphology, and syntax. So, the grammatical competences relates to the accurateness in the language accuracy. Second, sociolinguistic competence is the native speaker's ability in adapting the language use with the social environment where the language used. So, the sociolinguistic competence relates to the appropriateness in the social context as Hyme's theory that the language rules will useless if the language user ignores all the grammatical rules. Discourse competence tends to the ability of the language user in composing a discourse cohesively and coherently. Cohesively means that the idea or courses delivered in written or orally should be structurally using appropriate cohesive devices while coherently means that the idea or courses delivered should reflected the mind setting so the idea or courses delivered are easy to be understood. Third, strategic competence is an ability related to the use of verbal or non-verbal communication strategy in communicating caused by language knowledge limitation or other performance disruption such as lack of vocabulary, grammatical errors, incomplete utterances, etc.

\section{Component of English competences}

Bachman in Hadley (2001) elaborated two main components of language competences; they are organizational and pragmatically competences. The organizational competence includes grammatical and textual competences while pragmatically competence includes illocutionary and sociolinguistic competences. Specifically, grammatical competence includes vocabularies, morphology, and phonology. While textual competence includes cohesively, rhetorical, and organizational knowledge. Illocutionary competence refers to the language use in expressing idea, manipulating idea, using 
language to teach, studying, problem solving, and imagination. While sociolinguistic competence refers to dialect sensitivity, language neutrality, culture understanding and figures of speech.

Ferril (2013)stated that language competence related to one's conscious and unconscious acquisition and understanding receptive and productive skills. Those skills are developed for the learner in communicating four level literation; performative, functional, informational, and epistemic level. In the per formative level, learners are expected can read, write, listen, and speak using language symbols. In the functional level, learners are expected can use the language for daily life such as reading newspaper, instruction or direction. In the informational level, learners are expected can access information and knowledge through their proficiency. In the epistemic level, learners are expected can express the knowledge into target language.

Goweret all (2005) stated that those language skills are learned integratively. Brown (2001) called it as whole language approach and Orellana (2011) called it as integrated-skill-approach; all primary skills such as listening, reading, writing, speaking, vocabulary, spelling, pronunciation, syntax, word formation and other components must be integrated and optimalized in the communication. Gower mentioned that there are many advantages from teaching English integratively; (1) occuring meaningful language practice to develop learner's competence; (2) teaching two or more competences integratively; (3) occurring many material subjects; (4) giving teacher and learners an opportunity to explore the topics and practice the language more often; and (5) doing efficiency in the learning time.

Even though English learning is carried out integratively, one of the competences must be the main focus while the other competences are supporting skills in learning process. The integrated language competences and components in language learning can establish the competences in English language that is explained below.

\section{Listening Skill}

Listening skill is the first and the most basic skill developed by the learner in learning the first language, English as second language (ESL), or English as foreign language (EFL). Through listening, learner gets many language information as the basic for other language skills such as speaking, reading, and writing. Helgesen (2003) described that listening is an active process and aimed get the meaning from our hearing. Cameron (2008) stated that listening is basically the active language use in accessing the meaning delivered by others. Wilson (2008) added that listening is not pasive but active process; otherwise all activities are happened in the brain. So, it can be concluded that listening is active skill happened in the listener's brain in guessing, predicting, proofing, criticizing, and interpreting what the listener heard.

Richard (2008) explained that listening can be divided into two perspectives; listening as comprehension and as acquisition. Listening as comprehension is a common way to think about the nature of listening. In this perspective, listening and listening as comprehension are synonymous. It means that in learning the second language, it facilitates the comprehension toward oral courses. While, listening as acquisition views that listening is a part of language development. It means that the learners can develop their skill in using language items to produce oral language.

Buck (2001) described two steps in listening comprehension process; they are apprehension toward linguistic information from the message and application toward linguistic information wider. Richards (2008) identified two processes in listening; they are top-down and bottom-up processes. Top-down process refers to the prior knowledge in giving meaningful message, while bottom-up process is more focus on learner's understanding about language components. Harmer (2007) elaborated that listening skill help the ESL and EFL learners to develop the pronunciation and spelling by listening separated words or whole utterances. Brown (2001)added that listening skill as the basic of speaking skill. The learners would not be able to speak before doing listening first. Through listening, the learners can internalize the linguistic information then it is applied in speaking activities. 


\section{Speaking Skill}

Speaking is oral productive skill. Brown (2001) defined speaking as activity that involves two or more people in which the participants are both listeners and speakers having to act what they listen and make contribution meaningfully. It means that speaking involves two people or more in participating and contributing as the listener and speaker. Richards (2008) firmly stated that the success of ESL or EFL learners in learning English depends on their ability in speaking. Harmer (2007) explained that the ability of one's speaking fluently depends on the prior knowledge about language features and the ability in processing the information and language in the same time. It means that the ability of speaking fluently does not depend on many or less vocabulary acquired but the most important the speaker can speak their words, idea, or utterances spontaneously. Fulcher (2000) explained that the elements of speaking ability are grammar, vocabulary, pronunciation, fluency, and accuracy. Grammar is important in composing sentences correctly. Vocabulary is the basic composition in arranging sentences, the more vocabularies, the more expressive the learners. Correct pronunciation helps the listener to understand the speaker's utterances. Fluency is needed to make the conversation running well. The communication will have distraction when the communication is not fluent. Accuracy is also important in speaking because the conversation involves two people or more who needs the understanding of two people or more.

Harmer (2007) stated that there are few speaking genres. They are transactional and interpersonal; interactive and non-interactive; and planned and unplanned. Transactional genre aims to deliver the message and facilitating services or things, while interpersonal genre aims to maintain and continue the relationship between the speaker and listener. Interactive genre happens in two ways communication while non-interactive happens when someone leave the message on the phone. Then, planned genre happens in the class or speech, while unplanned genre happens spontaneously when the people meet in the street.

The process of speaking generally divided into four steps. They are pre-speaking, whilespeaking, post-speaking, and extension practice. First step is pre-speaking. In pre-speaking, the students are given a sequence time to prepare their speaking and teacher gives the correction on their speaking. There are three ways in doing pre-speaking; pre-task planning, pre-speaking support, and authentic input. In pre-task planning, the students are given the time to formulate the idea for their speaking. In pre-speaking support, the students are given the advise in vocabulary and information used for their speaking. While in authentic input, the students are given the example to speak through authentic media to make their speaking easier such as videos, audios, or audio visual media.

Second step is while-speaking. In the while-speaking activities, there are few activities that can be carried out such as speaking task, fluency technique, and forming automaticity. In speaking task, there are three activities; information gap, problem solving, and social monologue. In the information gap, the students can bridge the differences and do brainstorming. In the problem solving, the students can solve the problem collaboratively using English. In the social monologue, the students can discuss a certain issue in the society. The fluency technique can be carried out by asking the students to retell the topic being discussed for a few times. In the forming automaticity, the students are obligated to memorize vocabularies given by the teacher. Through this memorization, it is expected that the students use the vocabularies automatically.

Third step is post-speaking. In the post-speaking step, there are three activities of the accuracy on student's speaking. They are language focus, self-repair, and corrective feedback. Language focus activity refers to the student's ability in using the language accurately from the observation on target language, find the similarity and difference between target language and mother tongue and then integrate the new language into English language. In the self-repair activity, the students are directed to analyze and evaluate their own speaking based on their pronunciation, grammar, and vocabularies used. While in the corrective feedback, there are two kind of feedback; teacher and peer feedback; by analyzing the student's audio from previous speaking activities. The 
extension practice is carried out by doing task repetition. Task repetition is giving the revised task to the students. It aims to develop student's accuracy and fluency in using oral language.

\section{Reading Skill}

Reading is a receptive skill in formulating meaningful information delivered in a text. Nunan (2003) stated that reading is a process of absorbing information from written text and assosiating information with prior knowledge to establish a meaningful text. Kosak (2011) stated that reading is a skill to get messages, written symbols, understanding meaningful text, and teaching pronunciation. Reading relates to processes. They are identifying and comprehending the text. Identifying the text refers to the process to identify the written symbols related to oral language. While, comprehending the text refers to give the meaningful word, sentence, and text.

Reading is an important skill that must be required by the learner because by acquiring the reading skill well, the learner can understand the texts being read. Reading is the key for the learner to get many knowledge. Based on Kosak (2011), there are types of reading such as skimming, scanning, and close reading. First, skimming is a reading activity aims to introduce a material to the reader through fast reading to get general information. Second, scanning is a fast reading activity since the beginning until the end of text aims to get the specific information from the text. Third, close reading is a detailed reading activity aims to get the implicit and explicit meaning from the text.

In Woolley (2011), there are four aims of reading activity; code-breaker, meaning maker, text user, and text-analyst. First, code-breaker is an activity to understand a code and symbol in a semiotic system in a text, movie, etc. Second, meaning maker is an activity to give the text meaning by concluding the text from prior knowledge, the social and culture background. Third, text user is a learner who knows the text aims by using different ways based on the reader's social and culture background. Fourth, text-analyst is a reader who decides the conclusion from the text being analyzed.

Reading is a receptive skill like listening skill. So, the process of reading can be taken from bottom-up and top-down process. Bottom-up process means that the process of reading begins from the smallest language form such as letters, morphemes, syllables, words, phrases, grammar, and punctuation. Top-down process means that the process of reading using reader's intellectuality and experiences in understanding the text.

\section{Writing Skill}

Writing is a productive skill required by the learner in acquiring the target language. Harmer (2004)stated that writing is an important skill required by ESL or EFL learner and writing is a tool of communication because it expresses people's thought and feeling. For those people who cannot express their thought and feeling orally, they can express theirs in written. By writing, people can communicate messages to the readers traditionally using paper and pencil or modern using technology. Writing is a process to find and organize idea, compose, and revise.

Writing is a practical skill. It means that the more practice in writing, the more qualified writing they have. Practice makes better. So, this writing skill must be practiced and trained continuously to get the better writing. There are many reasons in writing for daily life such as listing, informing, pursuing, maintaining relationship, documenting, expressing feeling, experiencing, and observing. Next, Chitravelu et. al (2005) classified types of writing into three classification. First, personal writing is such as shopping listing, note taking, diary, daily journal, message and card. Second, transactional writing is such as business correspondence, memo, instruction, report, proposal, and advertisement. Third, creative writing is such as poem, poetry, short story, anecdote, fiction story, and humors.

According Peha (2002), there are few steps in writing processes. They are pre-writing, drafting, sharing, revising, editing, and assessing. In pre-writing, the writer makes concept, note taking and collect idea. It aims to collect the writer's idea before drafting. In drafting, the writer begins to write based on the concept. Next, the writer shares the writing to their peers. It aims to get the advice and suggestion to make their writing better. Then, the writer revises the writing using advice and suggestion from peers. The next step is editing. In editing, the writer does editing in their 
writing such as spelling, punctuation, and grammar. The last step is publishing the writing. The writer prepares their writing to be published. The writer can assess their writing independently or assessed by their teacher and peers.

\section{Grammar}

Brown (2001) stated that grammar is the system of rules governing the conventional arrangement and relationship of words in sentences. The words in sentences means the grammar unit contains of words, phrases, clauses, and sentences. Hartwell (1985) stated that grammar is a number of pattern in composing words and messages. Chitravelu et al (2005) noted that grammar is rules of language, governing the way in which words are put together to convey meaning in different contexts. Brown (2001) firmly stated that grammatical competence takes an important role in communicative competence, that is organizational competence contains of complex rules, grammar, and discourse. Without this organizational competence, the language used will be spoken disorderly.

There are few grammatical rules acquired by the learner. First, it is word order. Word order is positioning the sentences as the part of speech such as Noun, Adjective, Preposition, etc. Second, it is sentences components such as an article, inflectional verbs, pluralization, word derivation, etc. Third, it is language function such as introduction, giving an opinion, suggestion, advice, etc. Fourth, it is sentence connector such as compound and complex sentences, conjunction (and, or, but), and logical connectors (so, unless, therefore). Fifth, it is grammar used for written and oral language such as abbreviation rules (I'm, that'll, she'll, etc), that is not allowed in formal writing. Sixth, it is idioms. Idioms are the word choice for different meaning to deliver the different message.

\section{Pronunciation}

Pronunciation is a language component related to sounds and how to pronounce the sounds accurately, so the listener can receive the message. Cross (1991) classified the sounds in tow categories; segmental and supra segmental sounds. Segmental sounds are the language units' arrangement, while supra segmental sounds are the sound's features such as word stress, intonation, rhythm, etc. Pronunciation is one of important language components in using oral language. The student's fluency is based on the accuracy of student's pronunciation and the miss pronunciation can lead to misunderstanding in receiving message. So, it is important to give more attention on pronunciation in learning English.

Citravelu et al (2005) classified there are three pronunciation aspects; sounds, word stress, and intonation. Sounds contains of consonant and vocal sounds. There are twenty sounds and twenty four consonants. Some sounds are not belongs to EFL learner language become the difficulties for the learners to pronounce it correctly. Word stress is also categorized by three levels; primary stressing, secondary stressing, and uncrossing syllables. Sentences are using stressing to communicate the meaning. In the sentences, there two categories on stressing mark; marked stress and unmarked stress. The stressing used to show the emotional of the speaker. So, does the intonation. The intonation shows the speaker's feeling in speaking utterances. If the intonation is flat means that the speaker is not interested on the topic discussion. For example, in the sentence "You speak English, don't you?", if it is said in the flat intonation means that the speaker is sure that the listener can speak English, but if it is said in the raising intonation means that the speaker is not sure that the listener can speak English or the speaker wants to get more information.

\section{CONCLUSION}

\section{Definition of Competence}

Competence is simply defined as the one's ability established by knowledge and experiences to reach their purpose. In the psychology dictionary, Colman (2009) defined the competence as the capacity, skills, or the ability in doing something correctly and effectively. In line with Colman, Beams (2008)defined the competences as the quality of ability caused by the qualification and the ability in doing a task. Richards \& Rodgers (2003) defined the competences as the description of essential skills, knowledge, attitudes, and behaviors required for effective performance of a real-world task or activity. So, the competence is the useful ability includes skills, knowledge, attitudes, and behaviors 
acquired by the students in doing the real-world task or activity in the real life in form of social networking.

Permendiknas No 23/2006 explained that a competence is knowledge, behavior, and a skill needed by the students after the students experienced a learning process. Permendikbud No 54/2013 firmly explained that a competence is one's ability to behave, use a knowledge and skill to do many tasks given by the school and society. From those Permendiknas and Permendikbud legalized by the government, generally competence is including the three main components, they are knowledge, skill, and behavior. The basic differences between those regulations are in Permendiknas No 23/2006 determines knowledge aspect as the priority but in Permendikbud No 54/2013 determines behavior aspect as the priority. So, in Permendiknas No 23/2006, the knowledge is the central aspect followed by skill and behavior and in Permendikbud No 54/2013, the behavior is the central aspect followed by knowledge and skill. The proper of knowledge directs the one to be behaved and skilled based the one's knowledge. But, in Permendikbud No 54/2013, the learning process is more priority in building a good behavior built by the knowledge and followed by the skill. So, the students are expected having a good behavior based on their knowledge and realized by their skill.

\section{Communicative Competence}

Chomsky is the first expert showed the term of communicative competence in 1960 in his famous theory about transformational-generative grammar. Chomsky differentiated between competence and performance. Competence is defined as implicitly and explicitly knowledge towards language system of native speaker, while performance is defined as native speaker ability in producing language in the use of language.Hymens (1972) developed Chomsky's theory about competence and performance with his famous concept of communicative competence. Hymes noted that language competence is not only focus on native speaker's implicit knowledge toward language system from a certain language but it is more focus on the sociolinguistic context and aspect of language. Appropriateness in language is very important aspect because Hymes (1972)firmly stated that there are rules of use without which the rules of grammar would be useless. It means that there are many rules in language use and without the rules; the grammatical rules will be useless. It can be concluded that the grammatical rules required by native speaker of English will useless if the speaker ignores the grammatical rules in using the language.

Larsen-Freeman (2010) firmly stated that communicative competence is learner's competence using language appropriately in the certain social context. Achieving this aim, language learner must have integrative knowledge in three components such as linguistic form, meanings, and forms. Hyme's communicative competence are elaborated by Canale \& Swain (1980). Canale \& Swain proposed four competences as the basic communicative competence; they are grammatical, sociolinguistic, discourse, and strategic competences. First, the grammatical competences refers to acquire the system of language use including vocabularies, pronunciation, spelling, word formation and structure. In other words, the grammatical competences are including phonology, morphology, and syntax. So, the grammatical competences relates to the accurateness in the language accuracy. Second, sociolinguistic competence is the native speaker's ability in adapting the language use with the social environment where the language used. So, the sociolinguistic competence relates to the appropriateness in the social context as Hyme's theory that the language rules will useless if the language user ignores all the grammatical rules. Discourse competence tends to the ability of the language user in composing a discourse cohesively and coherently. Cohesively means that the idea or courses delivered in written or orally should be structurally using appropriate cohesive devices while coherently means that the idea or courses delivered should reflected the mind setting so the idea or courses delivered are easy to be understood. Third, strategic competence is an ability related to the use of verbal or non-verbal communication strategy in communicating caused by language knowledge limitation or other performance disruption such as lack of vocabulary, grammatical errors, incomplete utterances, etc. 


\section{Component of English competences}

Bachman in Hadley (2001) elaborated two main components of language competences; they are organizational and pragmatically competences. The organizational competence includes grammatical and textual competences while pragmatically competence includes illocutionary and sociolinguistic competences. Specifically, grammatical competence includes vocabularies, morphology, and phonology. While textual competence includes cohesively, rhetorical, and organizational knowledge. Illocutionary competence refers to the language use in expressing idea, manipulating idea, using language to teach, studying, problem solving, and imagination. While sociolinguistic competence refers to dialect sensitivity, language neutrality, culture understanding and figures of speech.

Ferril (2013)stated that language competence related to one's conscious and unconscious acquisition and understanding receptive and productive skills. Those skills are developed for the learner in communicating four level literation; performative, functional, informational, and epistemic level. In the performative level, learners are expected can read, write, listen, and speak using language symbols. In the functional level, learners are expected can use the language for daily life such as reading newspaper, instruction or direction. In the informational level, learners are expected can access information and knowledge through their proficiency. In the epistemic level, learners are expected can express the knowledge into target language.

Goweret all (2005) stated that those language skills are learned integratively. Brown (2001) called it as whole language approach and Orellana (2011) called it as integrated-skill-approach; all primary skills such as listening, reading, writing, speaking, vocabulary, spelling, pronunciation, syntax, word formation and other components must be integrated and optimalized in the communication. Gower mentioned that there are many advantages from teaching English integratively; (1) occurring meaningful language practice to develop learner's competence; (2) teaching two or more competences integratively; (3) occurring many material subjects; (4) giving teacher and learners an opportunity to explore the topics and practice the language more often; and (5) doing efficiency in the learning time.

Eventhough English learning is carried out integratively, one of the competences must be the main focus while the other competences are supporting skills in learning process. The integrated language competences and components in language learning can establish the competences in English language that is explained below.

\section{Listening Skill}

Listening skill is the first and the most basic skill developed by the learner in learning the first language, English as second language (ESL), or English as foreign language (EFL). Through listening, learner gets many language information as the basic for other language skills such as speaking, reading, and writing. Helgesen (2003) described that listening is an active process and aimed get the meaning from our hearing. Cameron (2008) stated that listening is basically the active language use in accessing the meaning delivered by others. Wilson (2008)added that listening is not pasive but active process; otherwise all activities are happened in the brain. So, it can be concluded that listening is active skill happened in the listener's brain in guessing, predicting, proofing, criticizing, and interpreting what the listener heard.

Richard (2008) explained that listening can be divided into two perspectives; listening as comprehension and as acquisition. Listening as comprehension is a common way to think about the nature of listening. In this perspective, listening and listening as comprehension are synonymous. It means that in learning the second language, it facilitates the comprehension toward oral courses. While, listening as acquisition views that listening is a part of language development. It means that the learners can develop their skill in using language items to produce oral language.

Buck (2001) described two steps in listening comprehension process; they are apprehension toward linguistic information from the message and application toward linguistic information wider. Richards (2008) identified two processes in listening; they are top-down and bottom-up processes. Top-down process refers to the prior knowledge in giving meaningful message, while bottom-up 
process is more focus on learner understands about language components. Harmer (2007) elaborated that listening skill help the ESL and EFL learners to develop the pronunciation and spelling by listening separated words or whole utterances. Brown (2001)added that listening skill as the basic of speaking skill. The learners would not be able to speak before doing listening first. Through listening, the learners can internalize the linguistic information then it is applied in speaking activities.

\section{Speaking Skill}

Speaking is oral productive skill. Brown (2001) defined speaking as activity that involves two or more people in which the participants are both listeners and speakers having to act what they listen and make contribution meaningfully. It means that speaking involves two people or more in participating and contributing as the listener and speaker. Richards (2008) firmly stated that the success of ESL or EFL learners in learning English depends on their ability in speaking. Harmer (2007) explained that the ability of one's speaking fluently depends on the prior knowledge about language features and the ability in processing the information and language in the same time. It means that the ability of speaking fluently does not depend on many or less vocabulary acquired but the most important the speaker can speak their words, idea, or utterances spontaneously. Fulcher (2000) explained that the elements of speaking ability are grammar, vocabulary, pronunciation, fluency, and accuracy. Grammar is important in composing sentences correctly. Vocabulary is the basic composition in arranging sentences, the more vocabularies, the more expressive the learners. Correct pronunciation helps the listener to understand the speaker's utterances. Fluency is needed to make the conversation running well. The communication will have destruction when the communication is not fluent. Accuracy is also important in speaking because the conversation involves two people or more who needs the understanding of two people or more.

Harmer (2007) stated that there are few speaking genres. They are transactional and interpersonal; interactive and non-interactive; and planned and unplanned. Transactional genre aims to deliver the message and facilitating services or things, while interpersonal genre aims to maintain and continue the relationship between the speaker and listener. Interactive genre happens in two ways communication while non-interactive happens when someone leave the message on the phone. Then, planned genre happens in the class or speech, while unplanned genre happens spontaneously when the people meet in the street.

The process of speaking generally divided into four steps. They are pre-speaking, whilespeaking, post-speaking, and extension practice. First step is pre-speaking. In pre-speaking, the students are given a sequence time to prepare their speaking and teacher gives the correction on their speaking. There are three ways in doing pre-speaking; pre-task planning, pre-speaking support, and authentic input. In pre-task planning, the students are given the time to formulate the idea for their speaking. In pre-speaking support, the students are given the advise in vocabulary and information used for their speaking. While in authentic input, the students are given the example to speak through authentic media to make their speaking easier such as videos, audios, or audio visual media.

Second step is while-speaking. In the while-speaking activities, there are few activities that can be carried out such as speaking task, fluency technique, and forming automaticity. In speaking task, there are three activities; information gap, problem solving, and social monologue. In the information gap, the students can bridge the differences and do brainstorming. In the problem solving, the students can solve the problem collaboratively using English. In the social monologue, the students can discuss a certain issue in the society. The fluency technique can be carried out by asking the students to retell the topic being discussed for a few times. In the forming automaticity, the students are obligated to memorize vocabularies given by the teacher. Through this memorization, it is expected that the students use the vocabularies automatically.

Third step is post-speaking. In the post-speaking step, there are three activities of the accuracy on student's speaking. They are language focus, self-repair, and corrective feedback. Language focus activity refers to the student's ability in using the language accurately from the 
observation on target language, find the similarity and difference between target language and mother tongue and then integrate the new language into English language. In the self-repair activity, the students are directed to analyze and evaluate their own speaking based on their pronunciation, grammar, and vocabularies used. While in the corrective feedback, there are two kinds of feedback; teacher and peer feedback; by analyzing the student's audio from previous speaking activities. The extension practice is carried out by doing task repetition. Task repetition is giving the revised task to the students. It aims to develop student's accuracy and fluency in using oral language.

\section{Reading Skill}

Reading is a receptive skill in formulating meaningful information delivered in a text. Nunan (2003) stated that reading is a process of absorbing information from written text and associating information with prior knowledge to establish a meaningful text. Kosak (2011) stated that reading is a skill to get messages, written symbols, understanding meaningful text, and teaching pronunciation. Reading relates to processes. They are identifying and comprehending the text. Identifying the text refers to the process to identify the written symbols related to oral language. While, comprehending the text refers to give the meaningful word, sentence, and text.

Reading is an important skill that must be required by the learner because by acquiring the reading skill well, the learner can understand the texts being read. Reading is the key for the learner to get much knowledge. Based on Kosak (2011), there are types of reading such as skimming, scanning, and close reading. First, skimming is a reading activity aims to introduce a material to the reader through fast reading to get general information. Second, scanning is a fast reading activity since the beginning until the end of text aims to get the specific information from the text. Third, close reading is a detailed reading activity aims to get the implicit and explicit meaning from the text.

In Woolley (2011), there are four aims of reading activity; code-breaker, meaning maker, text user, and text-analyst. First, code-breaker is an activity to understand a code and symbol in a semiotic system in a text, movie, etc. Second, meaning maker is an activity to give the text meaning by concluding the text from prior knowledge, the social and culture background. Third, text user is a learner who is knowing the text aims by using different ways based on the reader's social and culture background. Fourth, text-analyst is a reader who decides the conclusion from the text being analyzed.

Reading is as a receptive skill like listening skill. So, the process of reading can be taken from bottom-up and top-down process. Bottom-up process means that the process of reading begins from the smallest language form such as letters, morphemes, syllables, words, phrases, grammar, and punctuation. Top-down process means that the process of reading using reader's intellectuality and experiences in understanding the text.

\section{Speaking Skill}

Writing is a productive skill required by the learner in acquiring the target language. Harmer (2004) stated that writing is an important skill required by ESL or EFL learner and writing is a tool of communication because it expresses people's thought and feeling. For those people who cannot express their thought and feeling orally, they can express theirs in written. By writing, people can communicate messages to the readers traditionally using paper and pencil or modern using technology. Writing is a process to find and organize idea, compose, and revise.

Writing is a practical skill. It means that the more practice in writing, the more qualified writing they have. Practice makes better. So, this writing skill must be practiced and trained continuously to get the better writing. There are many reasons in writing for daily life such as listing, informing, pursuing, maintaining relationship, documenting, expressing feeling, experiencing, and observing. Next, Chitravelu et. al (2005) classified types of writing into three classification. First, is personal writing such as shopping listing, note taking, diary, daily journal, message and card. Second, transactional writing is such as business correspondence, memo, instruction, report, proposal, and advertisement. Third, creative writing is such as poem, poetry, short story, anecdote, fiction story, and humors. 
According Peha (2002), there are few steps in writing processes. They are pre-writing, drafting, sharing, revising, editing, and assessing. In pre-writing, the writer makes concept, note taking and collect idea. It aims to collect the writer's idea before drafting. In drafting, the writer begins to write based on the concept. Next, the writer shares the writing to their peers. It aims to get the advice and suggestion to make their writing better. Then, the writer revises the writing using advice and suggestion from peers. The next step is editing. In editing, the writer doesediting in their writing such as spelling, punctuation, and grammar. The last step is publishing the writing. The writer prepares their writing to be published. The writer can assess their writing independently or assessed by their teacher and peers.

\section{Grammar}

Brown (2001) stated that grammar is the system of rules governing the conventional arrangement and relationship of words in sentences. The words in sentences means the grammar unit contains of words, phrases, clauses, and sentences. Hartwell (1985) stated that grammar is a number of pattern in composing words and messages. Chitravelu et al (2005) noted that grammar is rules of language, governing the way in which words are put together to convey meaning in different contexts. Brown (2001) firmly stated that grammatical competence takes an important role in communicative competence, that is organizational competence contains of complex rules, grammar, and discourse. Without this organizational competence, the language used will be spoken disorderly.

There are few grammatical rules acquired by the learner. First, it is word order. Word order is positioning the sentences as the part of speech such as Noun, Adjective, Preposition, etc. Second, it is sentences components such as an article, inflectional verbs, pluralization, word derivation, etc. Third, it is language function such as introduction, giving an opinion, suggestion, advice, etc. Fourth, it is sentence connector such as compound and complex sentences, conjunction (and, or, but), and logical connectors (so, unless, therefore). Fifth, it is grammar used for written and oral language such as abbreviation rules (I'm, that'll, she'll, etc), that is not allowed in formal writing. Sixth, it is idioms. Idioms are the word choice for different meaning to deliver the different message.

\section{Vocabulary}

Hiebert and Kamil (2005)explained that vocabulary is the study about word and its meaning in establishing sentences. there are two kinds of vocabularies. They are receptive and productive vocabularies. Receptive vocabulary is a number of words meant by language user when they are listening and reading while productive vocabulary is a number of word meant by the language user when they are speaking and writing.

Vocabulary is the most important language component, without vocabularies ownership, a person cannot use the language. In other words, the vocabulary is a crucial component in using written and oral language. Richards \& Renandya (2008)noted that vocabulary is the core component in language proficiency as the basic of English skills such as listening, speaking, reading, and writing. So, for the beginner learner, vocabulary is the first component learnt before grammar and other language components. Chitravelu et al (2005) classified words as two categories; contents and function words. Content words are the specific words such as person, things, action, quality, and condition. Function words are the meaningless words but it showed the grammatical rules such as articles, conjunction, and prepositions.

\section{Pronunciation}

Pronunciation is a language component related to sounds and how to pronounce the sounds accurately, so the listener can receive the message. Cross (1991) classified the sounds in tow categories; segmental and supra segmental sounds. Segmental sounds are the language unit's arrangement, while supra segmental sounds are the sound's features such as word stress, intonation, rhythm, etc. Pronunciation is one of important language components in using oral language. The student's fluency is based on the accuracy of student's pronunciation and the miss pronunciation can lead to misunderstanding in receiving message. So, it is important to give more attention on pronunciation in learning English. 
Citravelu et al (2005) classified there are three pronunciation aspects; sounds, word stress, and intonation. Sounds contains of consonant and vocal sounds. There are twenty sounds and twenty four consonants'. Some sounds are not belongs to EFL learner language become the difficulties for the learners to pronounce it correctly. Word stress is also categorized by three levels; primary stressing, secondary stressing, and uncrossing syllables. Sentences are using stressing to communicate the meaning. In the sentences, there are two categories on stressing mark; marked stress and unmarked stress. The stressing used to show the emotional of the speaker. So, does the intonation. The intonation shows the speaker's feeling in speaking utterances. If the intonation is flat means that the speaker is not interested on the topic discussion. For example, in the sentence "You speak English, don't you?", if it is said in the flat intonation means that the speaker is sure that the listener can speak English, but if it is said in the raising intonation means that the speaker is not sure that the listener can speak English or the speaker wants to get more information.

\section{REFERENCES}

Beams, R. (2008). Assesment of Competence Using CBT. The University of Greenwich: School of Engineering.

Brown, H. D. (2001). Teaching by Principles: An Interactive Approach to Language Pedagogy. New York: Addison Wesley Longman, Inc.

Buck, G. (2001). Assessing Listening. Cambridge: Cambridge University Press

Cameron, L. (2008). Teacbing Language to Young Learners. Cambridge: Cambridge University Press.

Canale, M. \& Swain, M. (1980). "Theoretical Basis of Communicative Approaches to Second Language Teaching and Testing". Applied Linguistics Journal, 1 (1), 1-47.

Chitravelu, N. Sithamparan, S. \& Choon, T.S. (2005). ELT Methodology: Principles and Practice (2 ${ }^{\text {nd }}$ edition). Selangor Darul Ebsan: Oxford Fajar Sdn. Bhd

Chomsky, N. (1965). Aspects of Theory of Syntax. United States: Massachussets Insitute of Technology

Colman, A.M. (2009). A Dictionary of Psychology ( $3^{\text {rd }}$ edition). Oxford: Oxford University Press.

Cross, D. (1991). Practical Handbook of Language Teaching. London: British Library Cateloguing.

Ferril. (2013). Kompetensi Berbicara. http://berkarya.um.ac.id/2012/07/13/kompetensiberbahasa/ accessed on October 2019.

Fulcher, G. (2000). The Communicative Legacy in Language Testing. http://languagetesting.info/articles/store/FulcherCLT.pdf. Accessed on October 2019

Gower, R., Philip, D. \& Walters, S. (2005). Teaching Practice: A Handbook for Teacher Training. Thailand: Macmillan Education.

Hadley, A. O. (2001). Teaching Language in Context. Boston: Thomson Heinle.

Harmer. (2004). How to Teach English. Harlow, Essex: Pearson Education Limited.

Harmer. (2007). The Practice of English Language Teaching. Harlow, Essex: Pearson Education, Ltd.

Hartwell, P. (1985). Grammar, Grammars, and the Teaching of Grammar: An SLA Perspective. TESOL Quarterly, 40 (1), 83-107

Helgesen, M. (2003). Listening. In David Nunan (Ed.), Practical English Language Teaching. New York: McGraw Hill

Hiebert, E. H. \& Kamil, M. L. (2005). Teaching and Learning Vocabulary: Bringing Research to Practice. London: Lawrence Erlbaum Associates

Hymes, D. (1972). On Communicative Competence. Dalam J. B. Pride \& J. Holmes (Ed.), Sociolinguistics. Harmondsworth: Penguin Books, Ltd.

Kosak, M. (2011). The Types of Reading and Exercises for Teaching Reading. Acessed on October 2019 from http://www.e-osnova.ru/PDF/osnova 100 696.pdf

Larsen-Freeman, D. (2010). Techniques and Principles in Language Teaching. Oxford: Oxford University Press.

Nazir, M. (2003). Metode Penelitian. Jakarta : GhaliaIndonesia.

Nunan, D. (2003). Practical English Language Teaching. New York: McGraw Hill 
Shobikah, N.

Orellana, E. E. (2011). The Importance of Integrating Skills in the Teaching of English as a Foreign Language. Accessed on $\quad$ October 2019 from http://www.monografis.com/trabajos17/integrated-skills/integrated-skills.shtmlk.

Peha, S. (2002). The Writing Process Notebook. Accessed on October 2019 from http://www.ttms.org

Permendiknas No 23/2009, accessed on October 2019

Richard, J. C. \& Rodgers, T. S. (2003). Approaches and Methods in Language Teaching. Cambridge: Cambridge University Press

Richards, J. C. \& Renandya, W. A. (2002). Methodology in Language Teaching: An Anthology of Current Practice. Cambridge: Cambridge University Press

Richards, J. C. (2008). Teaching Listening and Speaking: From Theory to Practice. Cambridge: Cambridge University Press

Sarwono, Jonathan. (2006). Metode Penelitian Kuantitatifdan Kualitatif. Yogyakarta :Graha Ilmu

Wilson, J. J. (2008). How to Teach Listening. Essex: Pearson Education Limited.

Woolley, G. (2011). Reading Comprehension: Assisting With Learning Difficulties. Accessed on 